\title{
Ischemic myelopathy caused by fibrocartilaginous embolism in a horse
}

\author{
Welden Panziera ${ }^{1}$ Ronaldo Michel Bianchi ${ }^{1} \quad$ Paula Reis Pereira $^{2}$ Mariana Martins Flores ${ }^{1}$ \\ Monique Togni ${ }^{1}$ Roberta Carneiro da Fontoura Pereira ${ }^{3}$ Flávio De La Corte ${ }^{3}$ Rafael Almeida Fighera $^{4 *}$
}

${ }^{1}$ Programa de Pós-graduação em Medicina Veterinária, Área de Concentração em Patologia e Patologia Clínica Veterinária, Centro de Ciências Rurais (CCR), Universidade Federal de Santa Maria (UFSM), 97105-900, Santa Maria, RS, Brasil.

${ }^{2}$ Curso de Medicina Veterinária, Centro de Ciências Rurais (CCR), Universidade Federal de Santa Maria (UFSM), Santa Maria, RS, Brasil. ${ }^{3}$ Clínica de Equinos, Hospital Veterinário Universitário (HVU), Universidade Federal de Santa Maria (UFSM), Santa Maria, RS, Brasil. ${ }^{4}$ Laboratório de Patologia Veterinária (LPV), Universidade Federal de Santa Maria (UFSM), Centro de Ciências Rurais (CCR), Bairro Camobi, Santa Maria, RS, Brasil. *Corresponding author: anemiaveterinaria@yahoo.com.br.

ABSTRACT: This report described clinical, epidemiological, and pathological aspects of ischemic myelopathy caused by fibrocartilaginous embolism (FCE) in a 10-year-old, mixed breed gelding. Clinically, the horse presented acute hind limbs paralysis, with a clinical course of approximately 24 hours. At necropsy, no gross lesions were observed. Cross-sections of the spinal cord revealed focally extensive areas of malacia from the T10 to L4 segments. Focally extensive areas of liquefactive necrosis involving the gray matter and adjacent white matter were observed on histologic sections. The lumen of multiple blood vessels in the periphery of the necrotic areas was occluded by fibrocartilaginous emboli that strongly stained with alcian blue. Clinical signs, gross necropsy, and histological findings observed in this case were identical to those described in the literature for ischemic myelopathy caused by FCE in the horse and other species.

Key words: equine diseases, neurological disorder, ischemic myelopathy, pathology.

Mielopatia isquêmica associada a embolismo fibrocartilaginoso em um equino

RESUMO: Este relato descreve os aspectos epidemiológicos, clínicos e anatomopatológicos de um caso de mielopatia isquêmica por embolismo fibrocartilaginoso (FCE) em um equino, macho castrado, sem raça definida, com 10 anos de idade. Clinicamente, o equino apresentou paralisia aguda dos membros pélvicos com evolução de aproximadamente 24 horas. Na necropsia não foram observadas alterações. Após serem realizados vários cortes transversais na medula espinhal, observou-se área focalmente extensa de malacia entre o segmento T10 até L4. Histologicamente haviam áreas focalmente extensas de necrose de liquefação envolvendo a substância cinzenta e a substância branca adjacente. Múltiplos vasos sanguíneos da periferia das áreas de necrose estavam ocluídos por êmbolos fibrocartilaginosos, que reagiram fortemente pela técnica de azul alciano. Os sinais clínicos, as lesões macroscópicas e os achados histológicos observados neste caso, são idênticos aos descritos na literatura para FCE em equinos e nas demais espécies.

Palavras-chave: doenças de equinos, distúrbio neurológico, mielopatia isquêmica, patologia.

Ischemic myelopathy by fibrocartilaginous embolism (FCE) is a syndrome characterized by an acute, and non-progressive neurologic dysfunction that affects multiple species (ZACHARY, 2013; CANTILE \& YOUSSEF, 2016). It has been described in dogs (CAUZINILLE \& KORNEGAY, 1996; DYCE \& HOULTON, 1993; GANDINI et al., 2003; TESSER et al., 2009) and humans (UPPAL et al., 2004; ZACHARY, 2013), and rarely in horses (TAYLOR et al., 1977; FUENTEALBA et al., 1991; SEBASTIAN \& GILES, 2004; WALLING et al., 2011). The pathogenesis of this syndrome remains uncertain and several theories have been proposed to explain the origin offibrocartilaginous emboli. In all affected species the main clinical signs are acute and hyperacute, characterized by ataxia and paresis/paralysis of the hind limbs (ZACHARY, 2013; CANTILE \& YOUSSEF, 2016).

The aim of this note was to describe a case of ischemic thoracolumbar myelopathy caused by FCE in a horse, addressing the epidemiological, clinical, and pathological aspects of this condition.

A 10-year-old, mixed breed gelding from Santa Maria, Rio Grande do Sul, Brazil, presented hyperacute paralysis of the hind limbs, with clinical course of approximately 24 hours. The horse was found in a "dog sitting" posture with the hind limbs extended cranially and positioned between the forelimbs (Figure 1A). On clinical examination, the horse was alert and vital signs were within the normal range. Based on the presentation, the main 


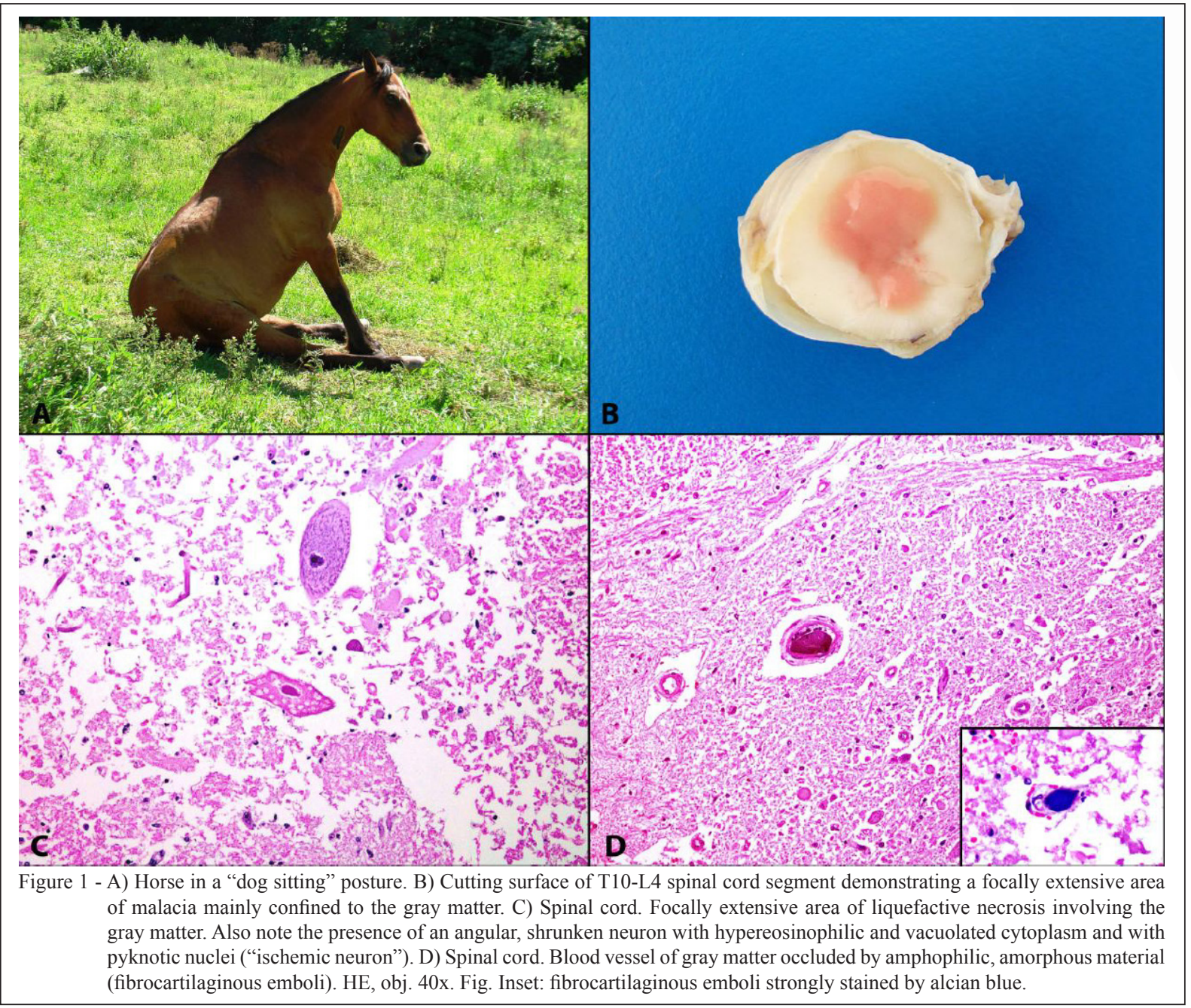

clinical diagnosis was a spinal cord thoracolumbar injury, most likely trauma (spinal cord trauma); although, a traumatic event was not observed. Due to poor prognosis, the owner opted for euthanasia and necropsy was performed.

During the necropsy no macroscopic lesions were observed. However, after fixation in $10 \%$ buffered formalin, focally extensive areas of softening and redness were identified on cross sections of the spinal cord, extending from the T10 to L4 spinal cord segments. Abnormalities were confined to the gray matter and involved both the dorsal and ventral horns (Figure 1B).

Histologically, on the different sections of spinal cord in the segment between T10-L4, there were focally extensive areas of liquefactive necrosis involving the gray matter and adjacent white matter. Multiple angular, shrunken neurons, with hypereosinophilic and occasionally vacuolated cytoplasm and pyknotic or absent nuclei ("ischemic neurons"), were noted (Figure 1C). Blood vessels in the periphery of the necrotic areas were occluded by amphophilic, amorphous material (emboli) (Figure 1D) that strongly stained with alcian blue and was interpreted as fibrocartilaginous emboli (Figure 1D inset). Marked vacuolation, with swollen myelin sheaths, and swollen, hypereosinophilic axons ("axonal spheroids") were present in white matter. The brain and other spinal cord segments were not affected.

Clinical signs, gross necropsy, and histological findings observed in this case were similar to those described in the literature for ischemic myelopathy caused by FCE in horses (TAYLOR et al., 1977; FUENTEALBA et al., 1991; SEBASTIAN \& GILES, 2004; WALLING et al., 2011). To the authors knowledge this is the first report of this condition in a horse in Brazil. 
In most cases, the emboli are histologically identical to the cartilage of the nucleus pulposus of the intervertebral disc (NEER, 1992; DYCE \& HOULTON, 1993; CAUZINILLE \& KORNEGAY, 1996), and the way which the emboli enter into the vasculature supplying the spinal cord remains uncertain. Arterial and venous pathways or the combination may be involved. Trauma and/or vigorous exercise may play an important role in the production of fibrocartilaginous embolism (FUENTEALBA et al., 1991; NEER, 1992). In this case, although there was no history of trauma or vigorous exercise, we cannot rule out these predisposing factors. Other causes of FCE include heavy musculature and rapid growth, diskospondylitis, and degenerative intervertebral disk disease (WALLING et al., 2011). There was no evidence of articular damage to suggest the diagnosis of intervertebral disk disease or any other lesion that could cause embolism.

Previous reports of FCE in horses do not mention a breed, sex, or age predisposition (TAYLOR et al., 1977; FUENTEALBA et al., 1991; SEBASTIAN \& GILES, 2004; WALLING et al., 2011). This syndrome is commonly reported in adult and elderly dogs, mainly in large and giant breeds (NEER, 1992; CAUZINILLE \& KORNEGAY, 1996; GANDINI et al., 2003; TESSER et al., 2009), which suggested that predisposing factors, including aging or a fissure of the annulus fibrosus, facilitate entry of nucleus pulposus material into the vasculature (NEER, 1992; CAUZINILLE \& KORNEGAY, 1996). Although, FCE cases in the horse are sporadic, all reports, including this one, are in adult horses, suggesting some similarity to the condition described in dogs.

Clinically, the horse of this case was found with acute paralysis of hind limbs and a "dog sitting" posture, which suggested spinal cord injury in the thoracolumbar segment, unlike cases of FCE described previously in the literature in horses (TAYLOR et al., 1977; FUENTEALBA et al., 1991; SEBASTIAN \& GILES, 2004; WALLING et al., 2011). Areas of hemorrhagic poliomalacia observed in the T10 to L4 spinal cord segment of this horse characterized ischemic myelopathy and is the most consistent gross finding observed in FCE in horses (FUENTEALBA et al., 1991; SEBASTIAN \& GILES, 2004) and in other species (ZACHARY, 2013; CANTILE \& YOUSSEF, 2016). Lesions were confined to the gray matter of the spinal cord and are related to a high metabolic rate and oxygen dependence of this region that is more susceptible to ischemic changes than the white matter (DYCE \& HOULTON, 1993). Reports of fibrocartilaginous embolism in horses have described asymmetric lesions that were limited to the cervical intumescence
(WALLING et al., 2011), differently from what was observed in this case. Asymmetric lesions, which are more common in the cranial portion of the spinal cord, are in part attributable to the distribution of unilateral and bilateral branches of the central arteries that arise from the ventral spinal artery (WALLING et al., 2011). This case suggested a previously unreported neuroanatomical region for the occurrence of FCE. The higher incidence of embolism in the cervicothoracic and thoracolumbar spinal cord segments may be due to the greater arterial supply (mainly in the intumescences) that increases the risk of mechanically projecting the pulpous nucleus into the spinal cord blood supply (CAUZINILLE \& KORNEGAY, 1996).

Histologically, poliomyelomalacia associated with the presence of emboli is the primary lesion identified in horses with FCE (TAYLOR et al., 1977; FUENTEALBA et al., 1991; SEBASTIAN \& GILES, 2004; WALLING et al., 2011). Emboli can be observed occluding vessels in the periphery of necrotic areas, as observed in this case, and/or in vessels of the meninges (ZACHARY, 2013; CANTILE \& YOUSSEF, 2016). Because of this, the histopathology is extremely important to confirm the diagnosis of FCE.

In the differential diagnosis of $\mathrm{FCE}$ in horses should be included disorders that present acute neurological conditions, mainly trauma (FUENTEALBA et al., 1991; SEBASTIAN \& GILES, 2004). In addition, other neurological condition should be listed, such as intervertebral disc protrusion with spinal cord compression (FOSS et al., 1983), discospondylitis, abscesses (ADAMS et al., 1985), rabies, neurological infection by herpesvirus, equine protozoal myeloencephalitis, wobbler syndrome due to cervical vertebral malformation (ZACHARY, 2013; CANTILE \& YOUSSEF, 2016) and post-anesthetic myelomalacia (JOUBERT et al., 2005).

\section{REFERENCES}

ADAMS S.B. et al. Diskospondylitis in five horses. Journal of the American Veterinary Medical Association, n.3, v.186, p.270-72, 1985. Available from: <http://europepmc.org/abstract/ med/3972688>. Accessed: December 05, 2015.

CANTILE C.; YOUSSEF S. Nervous System. In: MAXIE M.G. (Ed.). Jubb, Kennedy, and Palmer's Pathology of Domestic Animals. v.3. $6^{\text {th }}$ ed. Philadelphia: Saunders Elsevier, 2016, p.1-101.

CAUZINILLE L.; KORNEGAY J.N. Fibrocartilaginous embolism of the spinal cord in dogs: review of 36 histologically confirmed cases and retrospective study of 26 suspected cases. Journal of Veterinary Internal Medicine, n.4, v.10, p.241 45, 1996. Available from: $<$ http://onlinelibrary.wiley.com/doi/10.1111/j.1939-1676.1996. tb02056.x/full>. Accessed: December 05, 2015. doi: 10.1111/j.19391676.1996.tb02056.x. 
DYCE J.; HOULTON J.E.F. Fibrocartilaginous embolism in the dog. Journal of Small Animal Practice, n.32, p.332-336, 1993. Available from: <http://onlinelibrary.wiley.com/doi/10.1111/j.1748-5827.1993. tb02706.x/epdf> . Accessed: December 05, 2015. doi: 10.1111/j.17485827.1993.tb02706.x.

FOSS R.R. et al. Cervical intervertebral disc protrusion in two horses. Canadian Veterinary Journal, n.6, v.24, p.188-911, 1983. Available from: <https://www.ncbi.nlm.nih.gov/pmc/articles/PMC1790361/pdf/ canvetj00271-0040.pdf>. Accessed: December 05, 2015.

FUENTEALBA C. et al. Spinal cord ischemic necrosis due to fibrocartilaginous embolism in a horse. Journal of Veterinary Diagnostic Investigation, n3, p.176-79, 1991. Available from: $<$ http://vdi.sagepub.com/content/3/2/6.full.pdf $>$. Accessed: December 05, 2015. doi: $10.1177 / 104063879100300217$.

GANDINI G. et al. Fibrocartilaginous embolism in 75 dogs: clinical findings and factors influencing the recovery rate. Journal of Small Animal Practice. v.44, p.76-80, 2003. Available from: $<$ http://www. ncbi.nlm.nih.gov/pubmed/12622472>. Accessed: December 05, 2015. doi: 10.1111/j.1748-5827.2003.tb00124.x.

JOUBERT K.E. et al. Post-anaesthetic myelomalacia in a horse. Journal of the South African Veterinary Association, n. 1, v.76, p.36-39, 2005. Available from: $<$ https://pdfs.semanticscholar.org/09d4/267372929551 699333cd6225740b7a038c1a.pdf >. Accessed: December 05, 2015.

NEER T.M. Fibrocartilaginous emboli. Veterinary Clinics of North America: Small Animal Practice, n.4, v.22,p.1017-26, 1992. Available from: $<$ http://www.sciencedirect.com/science/article/pii/S0195561692500900>. Accessed: December 05, 2015. doi: 10.1016/S0195-5616(92)50090-0.
SEBASTIAN M.M.; GILES R.C. Fibrocartilaginous embolic myelopathy in a horse. Journal of Veterinary Medicine, n.7-8, v.51, p.341-43, 2004. Available from: <http://onlinelibrary.wiley. com/doi/10.1111/j.14390442.2004.00648.x >. Accessed: December 05, 2015. doi: 10.1111/j.1439-0442.2004.00648.x.

TAYLOR H.W. et al. Ischemic myelopathy caused by fibrocartilaginous emboli in a horse. Veterinary Pathology, n.5, v.14, p.479-81, 1977. Available from: <http://vet.sagepub.com/ content/14/5/479.short>. Accessed: December 05, 2015. doi: 10.1177/030098587701400507.

TESSER E.S. et al. Fibrocartilaginosus embolic myelopathy in a dog. Acta Scientiae Veterinariae, n.3, v.37, p.291-294, 2009. Available from: <http://www.ufrgs.br/actavet/37-3/PUB\%20846. pdf $>$. Accessed: July 30, 2015.

UPPAL S. et al. Spinal cord infarction secondary to nucleus pulposus embolization in pregnancy. Mod. Pathol. Modern Pathology, n.17, p.121-24, 2004. Available from: <http://www. nature.com/modpathol/journal/v17/n1/pdf/3800037a.pdf $>$. Accessed: December 05, 2015. doi: 10.1038/modpathol.3800037.

WALLING B.E. et al. Pathology in practice. Fibrocartilaginous embolism. Journal of the American Veterinary Medical Association, n.2, v.239, p.199-201, 2011. Available from: <http:// avmajournals.avma.org/doi/full/10.2460/javma.239.2.199>. Accessed: December 05, 2015. doi: 10.2460/javma.239.2.199.

ZACHARY J.F. Sistema nervoso. In: ZACHARY J.F.; MCGAVIN M.B (Eds.). Bases da Patologia em Veterinária. 5 ed. Rio de Janeiro: Elsevier, 2013, p.774-873. 